\title{
Heat Exchanger Modelling for Solar Organic Rankine Cycle
}

\author{
S.M. Situmbeko*, F.L. Inambao \\ University of KwaZulu-Natal, Durban, South Africa
}

\begin{abstract}
The paper presents work done on the development of a heat exchanger model suitable for incorporation into a low temperature solar thermal power cycle. In particular it presents the mathematical model comprising heat transfer, mass transfer, and convective heat transfer coefficients, and velocity and pressure drop correlations for single and two phase flows. The preliminary evaporator model is based on a counter flow double pipe configuration; the flow boiling process incorporates both convective and nucleate boiling. The shell side heat transfer fluid consists of ethylene glycol at $50 \%$ concentration; the tube side fluid flow is modelled on four candidate working fluids pre-selected from previous stages of the research study. The evaporator model is implemented on the engineering equation solver platform; following on the computer simulation results a further proposal is made for conversion of the model design into a feasible shell-and-tube heat exchanger. The outputs of the model study are in the form of the rate of heat exchange, size and type of the heat exchanger, whilst ensuring that the pressure drops and fluid velocities are within acceptable limits.
\end{abstract}

Keywords: low temperature solar thermal, convective and nucleate boiling, engineering equation solver.

\section{Introduction}

The paper presents research done on the design of heat exchangers for the low temperature solar thermal conversion system based on the organic Rankine cycle (ORC). Figure 1 shows the general configuration of the basic ORC cycle; the cycle constitutes three major components that involve thermal energy exchanges, being the solar collector, the evaporator and the condenser; a solar thermal conversion cycle may incorporate other types of heat exchangers such as a preheater, a superheater and a recuperator. This paper presents the development of a design model for an evaporator heat exchanger.

The evaporator heat exchanger, also known as a boiler or vapouriser, entails two types of heat exchanges, sensible and latent heat exchanges, the processes 2-3 and 3-4 respectively shown in the Temperature-entropy (T-s) diagram of figure 2 . In figure $2, \mathrm{~T}_{\mathrm{H}, \mathrm{i}}$ is the temperature of the heat transfer fluid at the entrance to the heat exchanger; it can also be considered equal to the solar thermal storage temperature, assuming minimum thermal losses in the piping connecting the two components; $\mathrm{T}_{\mathrm{H}, \mathrm{o}}$ is the return temperature of the heat transfer fluid after the heat exchange process; $\mathrm{T}_{\mathrm{H}, \mathrm{s}}$ is an arbitrary temperature along the heat transfer fluid flow stream that corresponds to the commencement of phase change along the working fluid flow stream; point 3 is otherwise also referred to as the pinch point.

\section{Description of Model}

In this part of the modelling process we develop a more detailed model of the evaporator. Specifying the heat exchanger type, materials as well as operating parameters. This information is helpful in the eventual specification of the heat exchanger to be incorporated in the solar power cycle.

The evaporator model is developed as two co-joined heat exchangers, the preheater for the sensible heating of the working fluid from the sub-cooled liquid state to the saturated liquid state and the vapouriser for the latent heating of the working liquid from the saturated liquid state to the saturated vapour state; the working fluids selected are those with nearto- isentropic turbine expansion thus not requiring superheating.

${ }^{*}$ Corresponding author. Tel.: +27710570753

Fax: +27 31260 1233; E-mail: ssitumbeko@yahoo.com

(C) 2015 International Association for Sharing Knowledge and Sustainability

DOI: $10.5383 /$ ijtee.09.01.002 
The evaporator heat exchanger is initially modelled as a double pipe counter current flow heat exchanger as shown in the following figure 3 ; other operating parameters are also listed in table 1 . In figure 3 , numbers 2,3 and 4 refer to fluid flow positions as in figures 1 and 2 .

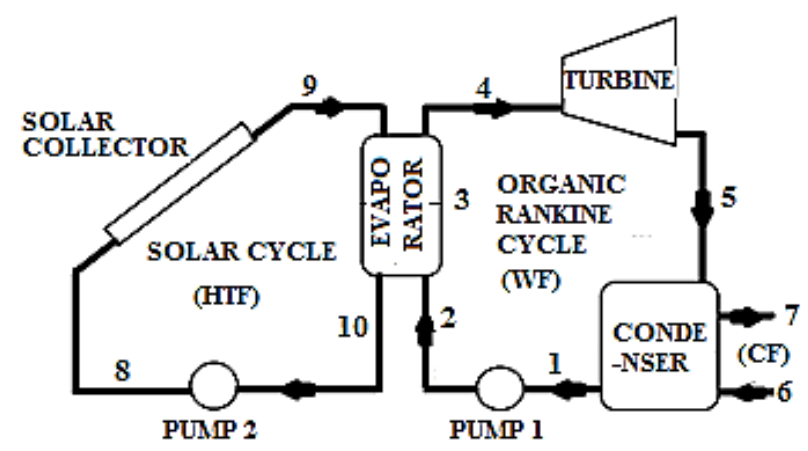

Figure 1: Heat cycle diagram [1]

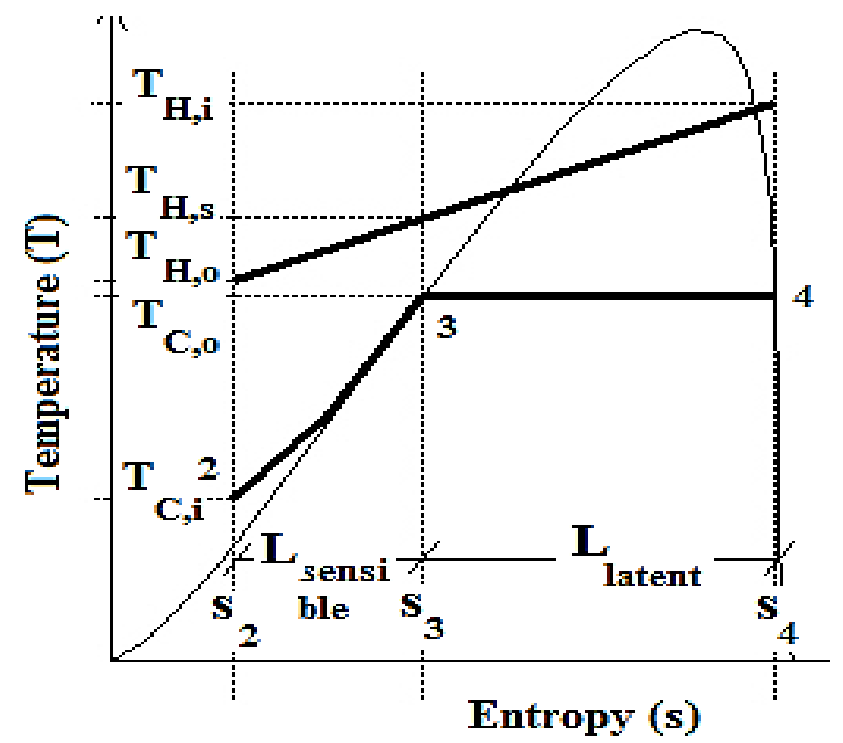

Figure 2: Temperature-Entropy diagram

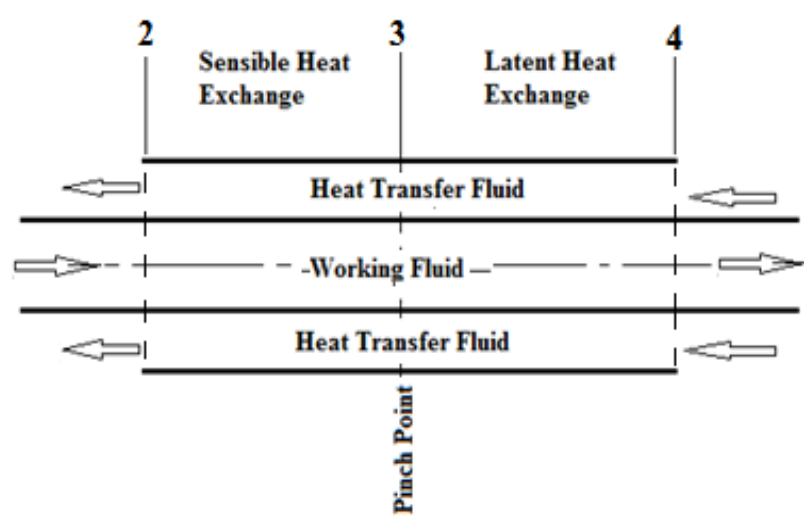

Figure 3: Evaporator heat exchanger model

The flow is assumed vertical; with the flow directions of the hot fluid (heat transfer fluid) being top-to-down in the outer pipe and that of the cold fluid (working fluid) being down-totop in the inner pipe (refer to flow directions shown in figure 1 ). The complete list of model parameters is as shown in table 1 below:
Table 1: double pipe heat exchanger parameters

\begin{tabular}{|c|c|}
\hline heat exchanger type & double pipe \\
\hline flow configuration & counter flow \\
\hline Thermal load required & $4.2,16.8,84.2 \mathrm{~kW}_{\text {th }}$ \\
\hline $\begin{array}{l}\text { Heat transfer fluid (hot } \\
\text { stream) }\end{array}$ & $\begin{array}{ll}\text { ethylene } & \text { glycol } \\
\text { concentration) } & \end{array}$ \\
\hline Working fluid (cold stream) & $\begin{array}{l}\text { any of:- } \\
\text { (i) n-butane; } \\
\text { (ii) isobutene; } \\
\text { (iii) R245fa; } \\
\text { (iv) R123 }\end{array}$ \\
\hline tube inside diameter & $\begin{array}{l}20 \mathrm{~mm} \text { (tube material: copper } \\
\text { alloy) }\end{array}$ \\
\hline tube outside diameter & $\begin{array}{l}23 \mathrm{~mm} \text { (tube material: copper } \\
\text { alloy) }\end{array}$ \\
\hline shell inside diameter & $\begin{array}{l}34 \quad \mathrm{~mm} \quad \begin{array}{l}\text { (determined } \\
\text { parametric simulations) }\end{array} \\
\end{array}$ \\
\hline $\begin{array}{l}\text { heat transfer fluid mass } \\
\text { flow rate }\end{array}$ & $\begin{array}{l}\text { Varying to acceptable velocity and } \\
\text { pressure drop }\end{array}$ \\
\hline $\begin{array}{l}\text { working fluid mass flow } \\
\text { rate }\end{array}$ & $\begin{array}{l}\text { varying depending on thermal load } \\
\text { and limits for velocity and pressure } \\
\text { drop }\end{array}$ \\
\hline cooling fluid mass flow rate & $\begin{array}{l}\text { varying depending on thermal load } \\
\text { and limits for velocity and pressure } \\
\text { drop }\end{array}$ \\
\hline $\begin{array}{l}\text { heat transfer fluid inlet } \\
\text { temperature }\end{array}$ & $90^{\circ} \mathrm{C}$ (from solar field model) \\
\hline $\begin{array}{llr}\text { working } & \text { fluid } & \text { inlet } \\
\text { temperature } & & \end{array}$ & $40^{\circ} \mathrm{C}$ \\
\hline $\begin{array}{l}\text { cooling fluid inlet } \\
\text { temperature }\end{array}$ & $25^{\circ} \mathrm{C}$ \\
\hline high cycle pressure & $\begin{array}{l}10 \text { atmosphere; varying to conform } \\
\text { with heat source temperature limit }\end{array}$ \\
\hline low cycle pressure & 3.5 atmosphere \\
\hline
\end{tabular}

Heat transfer fluid used is ethylene glycol (not simply water) because the solar energy systems are located outdoors and may not be operational at night thus requiring freeze protection and/or drainage capabilities.

\section{Mathematical Model}

The evaporator was initially modelled in the first pass system model simply as a change in enthalpy as shown below: [1]

$\frac{\dot{\mathrm{Q}}_{\text {evap }}}{\dot{\mathrm{m}}}=\left(\mathrm{h}_{\text {out }}-\mathrm{h}_{\text {in }}\right)$

Where:

$\dot{\mathrm{Q}}_{\text {evap }} \quad$ is the rate of heat transfer from the heat transfer fluid to the working fluid in the evaporator, (W);

$\dot{\mathrm{m}} \quad$ is the mass flow rate of the working fluid passing through the evaporator, $(\mathrm{kg} / \mathrm{s})$;

$\mathrm{h}_{\text {out }} \quad$ is the enthalpy of the working fluid exiting the evaporator, $(\mathrm{J} / \mathrm{kg}-\mathrm{K})$; and

$\mathrm{h}_{\text {in }} \quad$ is the enthalpy of the working fluid entering the evaporator, (J/kg-K).

In this study the mathematical model is developed as two cojoined models with common parameters at the interface, the pinch point. The model is based on the following heat exchange diagram, figure 4 : 


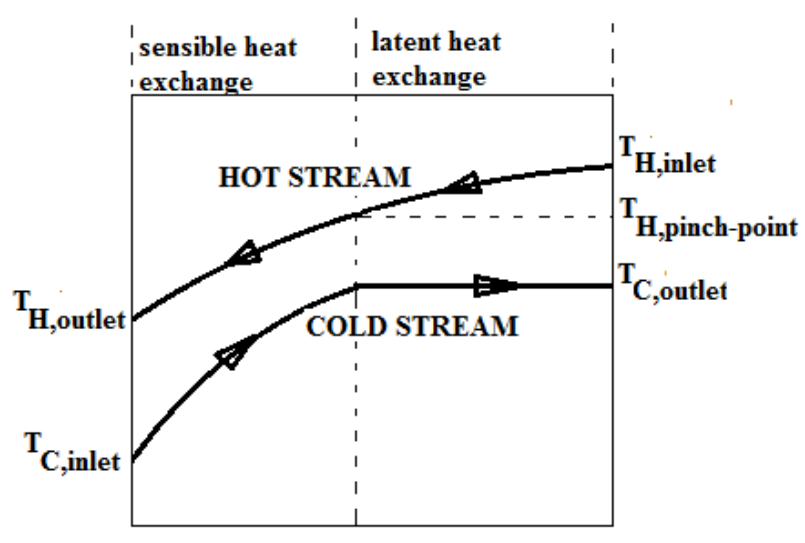

Figure 4: Heat transfer diagram

\subsection{Sensible Heat Exchange Model}

Heat transfer between the two streams can be expressed by equations 2, 3 and 4 as follows: [2]

$Q_{S}=U_{S, o} A_{S, o} \Delta T_{S, L M}$

where:

Qs $\quad$ is the heat transfer per unit time in the preheater section of the heat exchanger $(\mathrm{W})$;

$\mathrm{A}_{\mathrm{S}, \mathrm{o}} \quad$ is the heat transfer area on the outer surface of the inner pipe in the preheater section of the heat exchanger $\left(\mathrm{m}^{2}\right)$;

$\mathrm{U}_{\mathrm{S}, \mathrm{O}} \quad$ is the overall heat transfer coefficient on the outer surface of the inner pipe in the preheater section of the heat exchanger $\left(\mathrm{W} / \mathrm{m}^{2}\right)$; and

$\Delta \mathrm{T}_{\mathrm{S}, \mathrm{LM}} \quad$ is the logarithmic mean temperature difference in the preheater section of the heat exchanger, $\left({ }^{\circ} \mathrm{C}\right)$.

$Q_{S}=\dot{m}_{H} C p_{H}\left(T_{H, p i n c h-p o i n t}-T_{H, o u t l e t}\right)$

$Q_{s}=\dot{m}_{C} C p_{C}\left(T_{C, \text { outlet }}-T_{C, \text { inlet }}\right)$

where:

$\dot{m}_{H} \quad$ is the mass flow rate of the hot stream $(\mathrm{kg} / \mathrm{s})$;

$\dot{m}_{C} \quad$ is the mass flow rate of the cold stream $(\mathrm{kg} / \mathrm{s})$;

$C p_{H} \quad$ is the specific heat capacity of the hot stream fluid $\left(\mathrm{J} / \mathrm{kg}-{ }^{\circ} \mathrm{C}\right)$;

$C p_{C} \quad$ is the specific heat capacity of the cold stream fluid $\left(\mathrm{J} / \mathrm{kg}^{\circ}{ }^{\circ} \mathrm{C}\right)$; and

the temperatures are as shown in figure 4.

The convective heat transfer coefficients are obtained using either the Dittus-Boelter or the Sieder and Tate correlations; the EES code checks for validity and choses the appropriate one from the two. [3]

The Dittus-Boelter correlation is given by:
$N u_{D}=0.023 \operatorname{Re}_{D}{ }^{0.8} \operatorname{Pr}^{n}$

where:

$\mathrm{Nu}_{\mathrm{D}} \quad$ is the Nusselt number (dimensionless);

$\operatorname{Re}_{\mathrm{D}} \quad$ is the Reynolds number (dimensionless); and

$\operatorname{Pr} \quad$ is the Prandtl number (dimensionless);

$\mathrm{n}=0.4 \quad$ when fluid is being heated; and

$\mathrm{n}=0.3$ when fluid is being cooled.

This correlation is valid for:

$$
\left[\begin{array}{c}
0.7 \lesssim \operatorname{Pr} \lesssim 160 \\
R e_{D} \gtrsim 10000 \\
\frac{L}{D} \gtrsim 10
\end{array}\right]
$$

The Sieder and Tate correlation is given by:

$N u_{D}=0.027 \operatorname{Re}_{D}{ }^{4 / 5} \operatorname{Pr}^{1 / 3}\left(\frac{\mu}{\mu_{s}}\right)^{0.14}$

where:

$\mu \quad$ is the fluid viscosity at the bulk fluid temperature $(\mathrm{kg} / \mathrm{s}-\mathrm{m})$; and

$\mu_{\mathrm{s}} \quad$ is the fluid viscosity at the heat-transfer boundary surface temperature $(\mathrm{kg} / \mathrm{s}-\mathrm{m})$.

This correlation is valid for:

$$
\left[\begin{array}{c}
0.7 \lesssim \operatorname{Pr} \lesssim 16700 \\
R e_{D} \gtrsim 10000 \\
\frac{L}{D} \gtrsim 10
\end{array}\right]
$$

The fouling resistances are obtained from the EES program database [4]

R“_fo=FoulingFactor('Ethylene glycol solution')

R“_fi_S=FoulingFactor('Refrigerant liquids')

R“_fi_L=FoulingFactor('Refrigerant vapours')

The same fouling factors are used in the latent heat exchanger model in section 3.2.

\subsection{Latent Heat exchange Model}

In the latent section the model is segmented on account of the varying quality of the cold stream from saturated liquid to saturated vapour.

Each segment is thus modelled as:

$$
\begin{aligned}
Q_{L}[i] & =U_{L, o}[i] A_{L, o}[i] \Delta T_{L, L M}[i] \\
Q_{L}[i] & =\dot{m}_{H} C p_{H}[i]\left(T_{L, H}[i+1]-T_{L, H}[i]\right) \\
Q_{L}[i] & =\dot{m}_{C} h_{f g}(x[i+1]-x[i])
\end{aligned}
$$


where the letters $\mathrm{Q}, \mathrm{U}, \mathrm{A}, \Delta \mathrm{T}, \mathrm{Cp}, \mathrm{H}, \mathrm{C}$ and $\dot{m}$ have the same meanings and units as in section 3.1; while $\mathrm{L}$ stands for latent, $\mathrm{x}$ for quality of the vapour ( 0 for saturated liquid and 1 for saturated vapour); and ' $\mathrm{i}$ ' stands for the $\mathrm{i}$-th segment.

The segmentation is made as in figure 5:

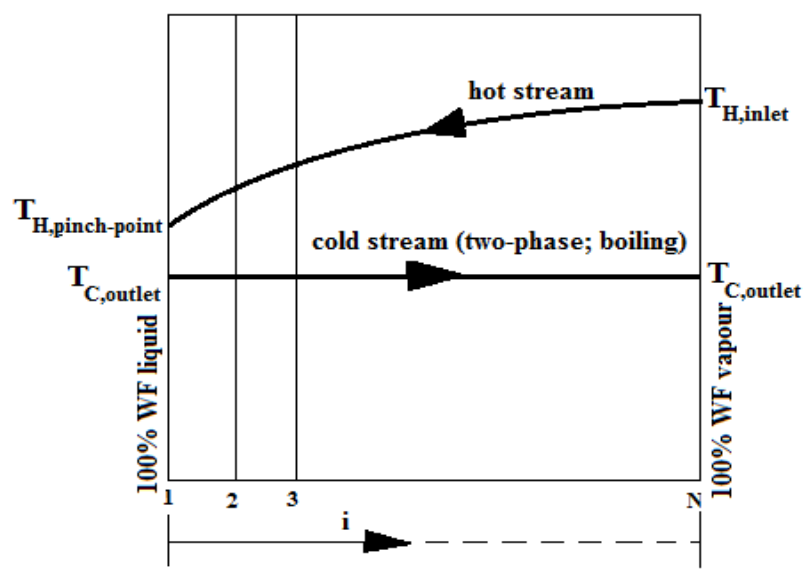

Figure 5: latent heat transfer diagram (showing segmentation direction)

The convective heat transfer coefficients for the latent heat exchange section are obtained using the Gnielinsk correlation for the hot stream and the Steiner and Taborek for the boiling stream (cold stream). Note that the Steiner and Taborek correlation also employs the Gnielinsk correlation; thus the Gnielinski correlation is given here in its general format hence the mention of liquid and vapour components.

The Gnielinsk correlation is given by:

$\frac{h_{L t} d_{i}}{k_{L}}=\frac{\left(f_{L} / 8\right)\left(R e_{L t}-1000\right) P r_{L}}{1+12.7\left(f_{L} / 8\right)^{1 / 2}\left(P r_{L}^{2 / 3}-1\right)}$

and the Fanning friction factor, $\mathrm{f}_{\mathrm{L}}$, for the liquid is:

$f_{L}=\left[0.7904 \ln \left(R e_{L t}\right)-1.64\right]^{-2}$

This expression is valid when $4000<\mathrm{Re}_{\mathrm{Lt}}<5000000$ and $0.5<\operatorname{Pr}_{L}<2000$ for single-phase flows. The total mass velocity of liquid plus vapour is used for evaluating the liquid Reynolds number, so that:

$R e_{L t}=\frac{\dot{m} d_{i}}{\mu_{L}}$

where:

$h_{L t} \quad$ is the local liquid-phase forced convection coefficient based on the total flow as liquid $\left(\mathrm{W} / \mathrm{m}^{2}{ }^{\circ} \mathrm{C}\right)$;

$d_{i} \quad$ is internal diameter of the pipe (m);

$k_{L} \quad$ is the local liquid-phase conductivity $\quad\left(\mathrm{W} / \mathrm{m}-{ }^{\circ} \mathrm{C}\right)$;

$\operatorname{Pr}_{L} \quad$ is the local liquid-phase Prandtl number (-);

$R e_{L t} \quad$ is the local liquid-phase Reynolds number (-);

$\dot{m} \quad$ is the total mass flow rate (of liquid and vapour) $(\mathrm{kg} / \mathrm{s})$; and;
$\mu_{\mathrm{L}}$ is the liquid-phase viscosity at the bulk fluid temperature $(\mathrm{kg} / \mathrm{s}-\mathrm{m})$;

The Steiner and Taborek (1992) comprehensive evaporation model for flow boiling in vertical tubes based on an asymptotic approach using an exponent equal to 3 is given by: [5]

$h_{t p}=\left[\left(h_{n b, o} F_{n b}\right)^{3}+\left(h_{L t} F_{t p}\right)^{3}\right]^{1 / 3}$

where:

$\mathrm{h}_{\mathrm{tp}} \quad$ is the total boiling coefficient $\left(\mathrm{W} / \mathrm{m}^{2}-{ }^{\circ} \mathrm{C}\right)$;

$\mathrm{h}_{\mathrm{nb}, \mathrm{o}}$ is the local nucleate pool boiling coefficient at a reference heat flux $\mathrm{q}_{\mathrm{o}}$ at the reduced pressure $\mathrm{p}_{\mathrm{r}}=0.1$, $\left(\mathrm{W} / \mathrm{m}^{2}-{ }^{\circ} \mathrm{C}\right)$;

$\mathrm{F}_{\mathrm{nb}}$ is the nucleate correction factor (but not a boiling suppression factor);

$h_{L t} \quad$ is the local liquid-phase forced convection coefficient based on the total flow as liquid and is obtained with the Gnielinski (1976) correlation, $\left(\mathrm{W} / \mathrm{m}^{2}{ }^{\circ}{ }^{\circ} \mathrm{C}\right)$; and

$F_{t p}$ is the two-phase multiplier that accounts for enhancement of liquid convection by the higher velocity of a two-phase flow of a liquid in a channel.

The standard nucleate boiling coefficients for the SteinerTaborek flow boiling correlation $\mathrm{h}_{\mathrm{nb}, \mathrm{o}}$ are provided in a table (not included in this paper) for the majority of working liquids at the following standard conditions: a reduced pressure of $\mathrm{pr}=$ 0.1 , a mean surface roughness of $R_{p, o}=1 \mu \mathrm{m}$ and the heat flux $\mathrm{q}_{\mathrm{o}}$ equal to the value listed for each fluid. The values in this table have been calculated using the Gorenflo correlation (1993).

Some liquids are not listed in the database (table); for these, any suitable correlation may be used; in this case we used the method due to Cooper(1984), [6] to calculate the local nucleate pool boiling coefficients at reduced pressure, $\mathrm{pr}=0.1$, surface roughness, $\mathrm{Rp}=1 \mu \mathrm{m}$, and $\mathrm{q}_{\mathrm{o}}$ equal $20000 \mathrm{~W} / \mathrm{m}^{2}$, as the case is for the majority of refrigerants in the table due to Gorenflo.

The Cooper model is given by:

$$
\begin{aligned}
& h_{n b, o}=55 p r^{(0.12-0.4343 \ln (R p))}(-0.4343 \ln (p r))^{-0.55} * \\
& M^{-0.5} q_{o}^{0.67}
\end{aligned}
$$

where 'pr' is the reduced pressure, 'Rp' is the surface roughness and ' $\mathrm{M}$ ' is the molar mass.

\subsection{Pressure Drop Correlations}

Pressure drop in a fluid circuit results from a number of sources such as circuit components, ducting, and accessories such as headers, manifolds and nozzles. Circuit components maybe tanks, collectors, heat exchangers etc. As the fluid has to be circulated through the circuit, it therefore means the pumping power required is associated with the pressure drop; and since pumping power has an economic factor on the circuit design, pressure drop in a heat exchanger becomes a design constraint or factor that has to be considered in heat exchanger designs. 
The pressure drop in a heat exchanger is a combination of four types namely: (a) frictional losses consisting of skin friction, form drag and internal contractions and expansions; (b) momentum effects due to fluid density changes; (c) gravity effects due to changes in elevation between inlet and outlet; and (d) inlet and outlet losses due to sudden contraction and expansion at the inlet and outlet.

\subsubsection{Single Phase Flow Pressure Drop Correlations [7]}

The tube side pressure drop is given as:

$\Delta P_{t}==\frac{f G_{t}^{2} L n}{2 g \rho_{t} d_{i} \Phi_{t}}$

where:

f is the friction factor;

$\mathrm{G}_{\mathrm{t}} \quad$ is the mass velocity of the fluid $\left(\mathrm{kg} / \mathrm{s}-\mathrm{m}^{2}\right)$;

$\mathrm{L} \quad$ is the length of the tube, $(\mathrm{m})$;

g is the acceleration due to gravity, $=9.8 \mathrm{~m} / \mathrm{s}^{2}$;

$\rho_{\mathrm{t}} \quad$ is the density of the fluid $\left(\mathrm{kg} / \mathrm{m}^{3}\right)$;

$\mathrm{d}_{\mathrm{i}} \quad$ is the inside diameter of the tube, $(\mathrm{m})$;

$\mathrm{n} \quad$ is the number of tube passes;

$\Delta \mathrm{P}_{\mathrm{t}} \quad$ is the pressure drop, $(\mathrm{Pa})$; and

$\phi_{\mathrm{t}} \quad$ is the dimensionless viscosity ratio; $\Phi_{t}=\left(\frac{\mu_{\infty}}{\mu_{s}}\right)^{0.14}$;

where $\mu_{\infty}$ the viscosity of the fluid at the bulk temperature; and $\mu_{\mathrm{s}}$ is the viscosity of the fluid at the film temperature.

In a multi-pass exchanger, in addition to frictional loss there is also a pressure drop referred to as return loss and expressed as:

$\Delta P_{r}=4 n\left(\frac{V^{2}}{2 g}\right) \rho_{t}$

where:

$\mathrm{n} \quad$ is the number of tube passes; and

$\mathrm{V}$ is the linear velocity of the tube fluid $(\mathrm{m} / \mathrm{s})$.

Thus the total tube-side pressure drop is given as:

$\Delta P_{T}=\Delta P_{t}+\Delta P_{r}$

For the shell side if we assume an unbaffled layout, the pressure drop is given as:

$\Delta P_{S}=\frac{f_{S} G_{S}^{2} L N}{2 g \rho_{S} D_{H} \Phi_{S}}$

where:

L is the shell length, (m);

$\mathrm{N} \quad$ is the number of shell passes;

$\rho_{\mathrm{s}} \quad$ is the shell fluid density, $\left(\mathrm{kg} / \mathrm{m}^{3}\right)$;

$\mathrm{G}_{\mathrm{s}} \quad$ is the shell-side mass velocity, $\left(\mathrm{kg} / \mathrm{m}^{2}-\mathrm{s}\right)$;

$\mathrm{D}_{\mathrm{H}} \quad$ is the hydraulic diameter of the shell, (m); and

$\phi_{\mathrm{s}} \quad$ is viscosity correction factor for shell-side fluid;
$\Phi_{S}=\left(\frac{\mu_{\infty}}{\mu_{s}}\right)^{0.14}$

\subsubsection{Two Phase Flow Pressure Drop Correlations[8]}

The total pressure drop in a two-phase flow can be calculated as follows:

$\Delta p=\Delta p_{s}+\Delta p_{f}+\Delta p_{m}+\Delta p_{g}$

For the tube side flow the friction pressure drop can be presented as:

$$
\begin{gathered}
\Delta p_{f}=\Delta p_{f, l o} \varphi^{2}{ }_{l o}=f_{l o} \frac{2 L}{D_{h}} \frac{G^{2}}{g_{c} \rho_{l}} \varphi^{2}{ }_{l o} \text { or } \Delta p_{f}=\Delta p_{f, v o} \varphi^{2}{ }_{v o}= \\
f_{v o} \frac{2 L}{D_{h}} \frac{G^{2}}{g_{c} \rho_{v}} \varphi^{2}{ }_{v o}
\end{gathered}
$$

where $\mathrm{f}_{\mathrm{lo}}$ and $f_{v o}$ represent the single-phase Fanning friction factor (the total mass flow rate as liquid or vapour, respectively, $\mathrm{f}_{\mathrm{lo}}$ equal to $16 / \mathrm{Re}_{\mathrm{lo}}$ for $\mathrm{Re}_{\mathrm{lo}}=G D_{h} / \mu_{l}<2000$, and $\mathrm{f}_{\mathrm{lo}}=0.079\left(\mathrm{Re}_{\mathrm{lo}}{ }{ }^{-0.25}\right.$ for $\left.\mathrm{Re}_{\mathrm{lo}}>2000\right)$. The pressure drop two phase friction multipliers $\varphi_{\text {lo }}^{2}$ and $\varphi^{2}{ }_{\text {vo }}$ are determined from some correlations such as Friedel, Chisholm, and LockhartMartinelli.

The momentum pressure drop can be calculated by integrating the momentum balance equation, thus obtaining:

$\Delta p_{m}=\frac{G^{2}}{g_{c}}\left[\left(\frac{x^{2}}{\alpha \rho_{v}}+\frac{(1-x)^{2}}{(1-\alpha) \rho_{l}}\right)_{z=z 2}-\left(\frac{x^{2}}{\alpha \rho_{v}}+\frac{(1-x)^{2}}{(1-\alpha) \rho_{l}}\right)_{z=z 1}\right]$

where ' $\alpha$ ' represents the void fraction of the vapour (gas) phase.

Finally, the pressure drop caused by the gravity (hydrostatic) effect is:

$\Delta p_{g}= \pm \frac{g}{g_{c}} \sin \theta \int_{o}^{L}\left[\alpha \rho_{v}+(1-\alpha) \rho_{l}\right] d z$

where the negative sign (i.e., the pressure recovery) stands for a downward flow in an inclined or vertical fluid flow.

\subsubsection{Allowable pressure drop and velocities}

Allowable pressure drop for both streams. This is a very important parameter for heat exchanger design. Generally, for liquids, a value of $0.5-0.7 \mathrm{~kg} / \mathrm{cm} 2(49.03-68.65 \mathrm{kPa})$ is permitted per shell. A higher pressure drop is usually warranted for viscous liquids, especially in the tube-side. For gases, the allowed value is generally $0.05-0.2 \mathrm{~kg} / \mathrm{cm} 2(4.903-$ $19.61 \mathrm{kPa})$, with $0.1 \mathrm{~kg} / \mathrm{cm} 2(9.807 \mathrm{kPa})$ being typical. The velocity limits are: [9], [10]

Shell side velocity $0.5 \leq \mathrm{V}_{\mathrm{s}} \leq 2(\mathrm{~m} / \mathrm{s})$

Tube side velocity $1 \leq \mathrm{V}_{\mathrm{t}} \leq 3(\mathrm{~m} / \mathrm{s})$

\section{Computer Simulations}

Simulations are performed on the EES platform [11]; the simulation code consists of two sub-codes, one for the preheater and another for the vapouriser. 
The simulations were done for each of the four candidate working fluids and for each of the three thermal loads of 4.2 $\mathrm{kW}_{\text {th }}, 16.8 \mathrm{~kW}_{\text {th }}$ and $84.2 \mathrm{~kW}_{\text {th }}$ respectively representing cycles with power outputs of $0.5 \mathrm{~kW}_{\mathrm{e}}, 2 \mathrm{~kW}_{\mathrm{e}}$ and $10 \mathrm{~kW}_{\mathrm{e}}$; the thermal loads were determined from cycle efficiencies in the range 10$15 \%$ obtained from the initial system model thus giving an average cycle efficiency of $12.5 \%$. [1]

Parametric simulations were done in two runs; in the first run, the shell diameter (outer pipe was varied from an initial assumed value of $0.026 \mathrm{~m}$ in increments of $0.002 \mathrm{~m}$ until acceptable pressure drops and velocities were attained at $0.034 \mathrm{~m}$. In the second set the shell diameter was kept constant at $0.034 \mathrm{~m}$ with tube diameters maintained at 0.020 and 0.023 $\mathrm{m}$ respectively for inside and outside; while the glycol mass flow rate was varied from $0.5-5 \mathrm{~kg} / \mathrm{s}$ in increments of $0.5 \mathrm{~kg} / \mathrm{s}$ until the code responded with a 'non-convergence' error message. Output parameters were mass flow rate for the working fluid, heat exchanger area and length, pressure drops and velocities, temperatures and overall heat transfer coefficients. It is also important to note that the high cycle operational pressure was constrained for each working fluid by the thermodynamic requirement that the saturation temperature must lie below the heat source temperature, $90^{\circ} \mathrm{C}$; as shown in table 2; these value were determined in preliminary trial runs were the pressure was varied; the initial value of 10 atmospheres was determined from comparisons with typical operating conditions for similar cycles $(10$ to 30 atmospheres)[12], [13], and also with higher pressure steam cycles operating in the 100 to 300 atmospheres. [14], [15].

Table 2: high cycle pressure and saturation temperature

\begin{tabular}{|l|l|l|}
\hline Working Fluid & $\begin{array}{l}\text { Saturation Pressure } \\
(\mathbf{k P a})\end{array}$ & $\begin{array}{l}\text { Saturation } \\
\text { Temperature } \\
\left({ }^{\mathbf{}} \mathbf{C}\right)\end{array}$ \\
\hline n-butane & 1010 & 80.03 \\
\hline isobutane & 1010 & 66.82 \\
\hline R123 & 506.6 & 81.35 \\
\hline R245fa & 810.6 & 80.99 \\
\hline
\end{tabular}

\section{Results}

The complete set of results is shown in the appendix. Table 3 shows the most optimal results in terms of minimum heat exchanger size that satisfies the velocity and pressure drop requirements; the results are presented for each of the three thermal loads and for each of the four working fluids. In cases where the selection requirements are not met the closest option has been selected; this is especially so with the $84.2 \mathrm{kWth}$ thermal load.

Other results are shown in plots in figures 6 to 14. The plots in figures $6,7,8,9,10$ and 12 show the variation of shell side pressure drop and heat exchanger length with shell side mass flow rate; figure 11 shows the variation of tube side pressure drop with shell side mass flow rate. Finally figures 13 and 14, show the variation of tube side fluid velocity and mass flow rate with thermal load.
Table 3: Summarised Heat Exchanger Design Data

\begin{tabular}{|c|c|c|c|c|c|}
\hline $\begin{array}{r}\text { Working } \\
\text { Fluid }\end{array}$ & $\begin{array}{l}\text { Thermal } \\
\text { Load } \\
(\mathrm{kWth})\end{array}$ & $\begin{array}{l}\mathrm{n}- \\
\text { butane }\end{array}$ & $\begin{array}{l}\text { isobuta } \\
\text { ne }\end{array}$ & R123 & R245fa \\
\hline \multirow{3}{*}{$\begin{array}{l}\text { Total Heat } \\
\text { Exchanger } \\
\text { Length }(\mathrm{m})\end{array}$} & 4.2 & 8.758 & 4.114 & 10.901 & 10.418 \\
\hline & 16.8 & 27.398 & 11.423 & 34.02 & 32.020 \\
\hline & 84.2 & 171.41 & 48.790 & 186.02 & 240.57 \\
\hline \multirow{3}{*}{$\begin{array}{l}\text { Total Shell } \\
\text { Side } \\
\text { Pressure } \\
\text { Drop }(\mathrm{kPa})\end{array}$} & 4.2 & 3.980 & 1.880 & 4.960 & 4.740 \\
\hline & 16.8 & 12.530 & 5.250 & 15.970 & 14.640 \\
\hline & 84.2 & 267.74 & 76.510 & 430.48 & 375.82 \\
\hline \multirow{3}{*}{$\begin{array}{l}\text { Total Tube } \\
\text { Side } \\
\text { Pressure } \\
\text { Drop }(\mathrm{kPa})\end{array}$} & 4.2 & 0.002 & 0.001 & 0.004 & 0.003 \\
\hline & 16.8 & 0.058 & 0.032 & 0.131 & 0.108 \\
\hline & 84.2 & 6.354 & 2.428 & 12.206 & 14.219 \\
\hline \multirow{3}{*}{$\begin{array}{l}\text { Maximum } \\
\text { Shell Side } \\
\text { Velocity } \\
(\mathrm{m} / \mathrm{s})\end{array}$} & 4.2 & 1.993 & 1.993 & 1.993 & 1.993 \\
\hline & 16.8 & 1.993 & 1.993 & 1.993 & 1.993 \\
\hline & 84.2 & 3.985 & 3.985 & 4.982 & 3.985 \\
\hline \multirow{3}{*}{$\begin{array}{l}\text { Maximum } \\
\text { Tube Side } \\
\text { Velocity } \\
(\mathrm{m} / \mathrm{s}) \\
\end{array}$} & 4.2 & 0.066 & 0.078 & 0.053 & 0.054 \\
\hline & 16.8 & 0.263 & 0.312 & 0.214 & 0.216 \\
\hline & 84.2 & 1.317 & 1.566 & 1.070 & 1.080 \\
\hline
\end{tabular}

\subsection{Thermal Load: $4.2 \mathrm{kWth}$}

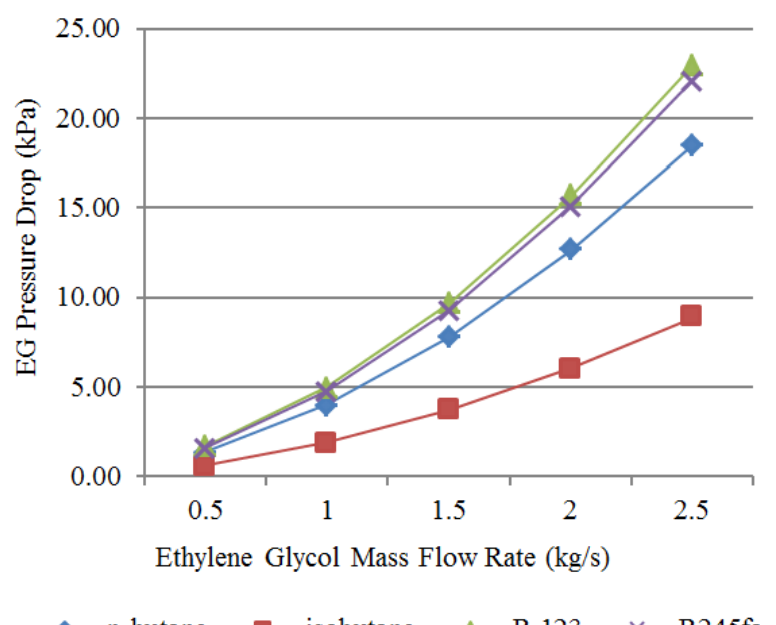

Figure 6: variation of shell side pressure drop with shell side mass flow rate for $4.2 \mathrm{kWth}$ thermal load

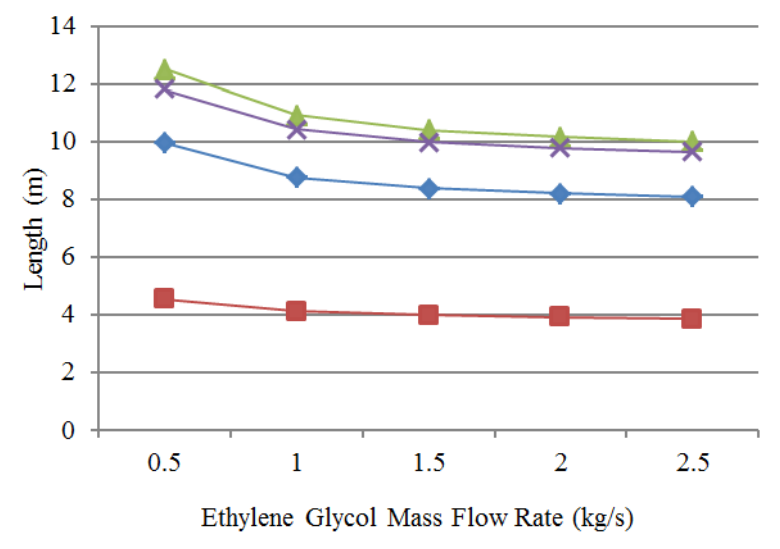

$\longrightarrow$ n-butane $\longrightarrow$ isobutane $\longrightarrow$ R $123 \longrightarrow$ R245fa

Figure 7: variation of heat exchanger length with shell side mass flow rate for $4.2 \mathrm{~kW}$ th thermal load 


\subsection{Thermal Load: $16.8 \mathrm{kWth}$}

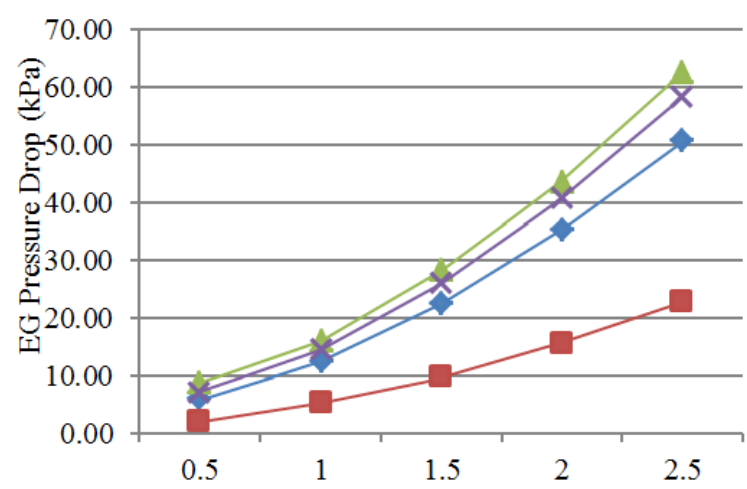

Ethylene Glycol Mass Flow Rate $(\mathrm{kg} / \mathrm{s})$

$$
\begin{array}{ll}
\longrightarrow \text { n-butane } & \longrightarrow \text { isobutane } \\
\longrightarrow \text { R } 123 & \leftarrow \text { R245fa }
\end{array}
$$

Figure 8: variation of shell side pressure drop with shell side mass flow rate for $16.8 \mathrm{~kW}$ th thermal load

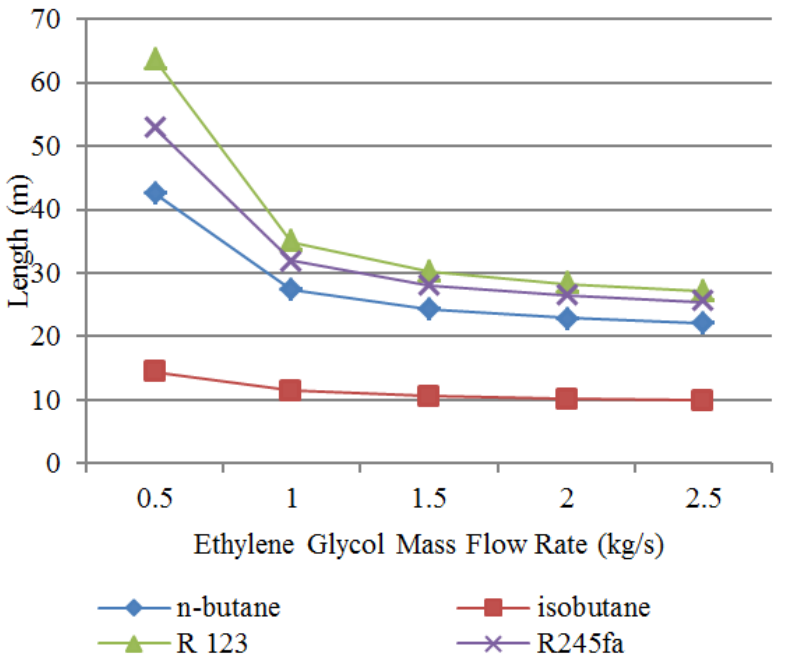

Figure 9: variation of heat exchanger length with shell side mass flow rate for $16.8 \mathrm{kWth}$ thermal load

\subsection{Thermal Load: $84.2 \mathrm{kWth}$}

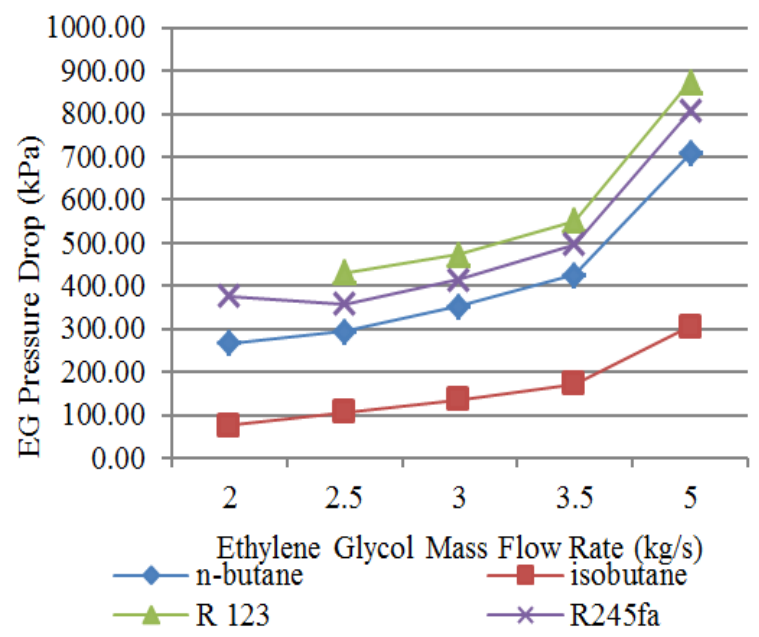

Figure 10: variation of shell side pressure drop with shell side mass flow rate for $84.2 \mathrm{~kW}$ th thermal load

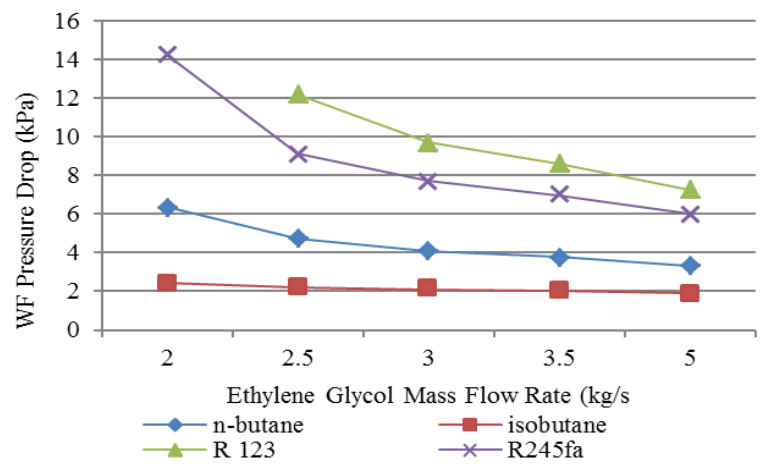

Figure 11: variation of tube side pressure drop with shell side mass flow rate for $84.2 \mathrm{~kW}$ th thermal load

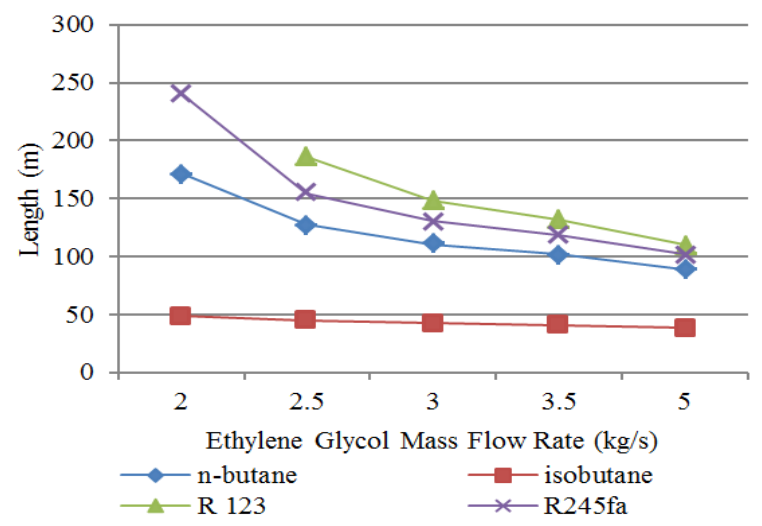

Figure 12: variation of heat exchanger length with shell side mass flow rate for $84.2 \mathrm{~kW}$ th thermal load

\subsection{Other Results}

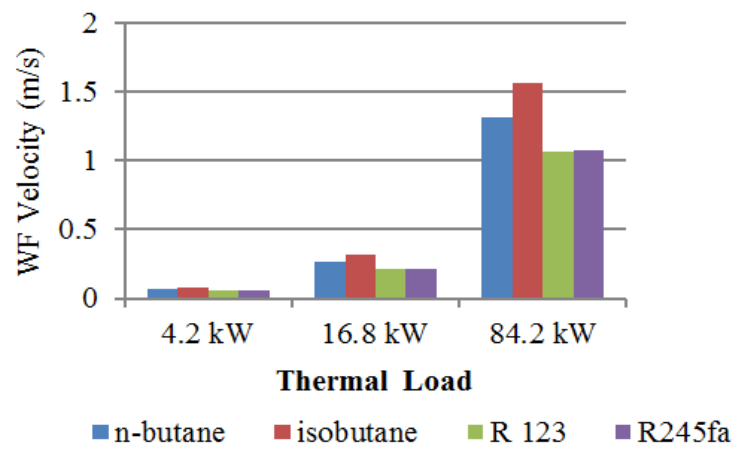

Figure 13: variation of tube side maximum velocity with working fluid type for all thermal loads

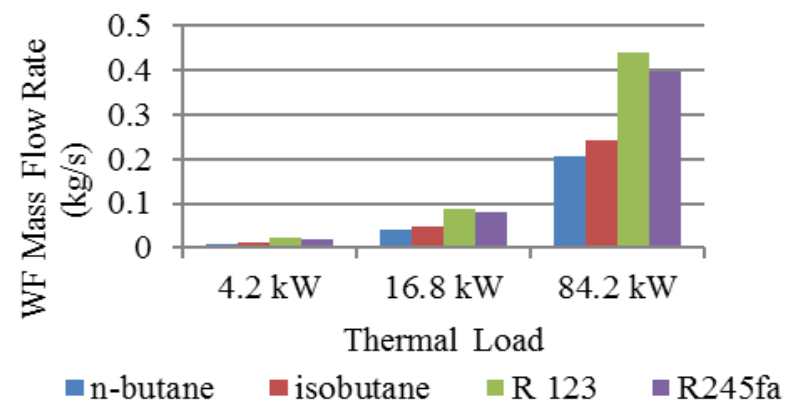

Figure 14: variation of tube mass flow rate with working fluid type for all thermal loads 


\section{Discussions}

For thermal loads 4.2 and $16.8 \mathrm{~kW}_{\text {th }}$ the double pipe heat exchanger is adequate in terms of both material and manufacturing costs (size) and operational costs (pressure drop and velocity limits).

For the $84.2 \mathrm{~kW}_{\text {th }}$ thermal load there is need to reconfigure the heat exchanger into a shell and tube or plate heat exchanger. Assuming a tube length of $5 \mathrm{~m}$ as acceptable a simple conversion to a single pass shell and single pass tube configuration is proposed as in table 4 .

Table 4: Preliminary heat exchanger design configurations

\begin{tabular}{|l|l|l|l|}
\hline $\begin{array}{l}\text { Working } \\
\text { Fluid }\end{array}$ & $\begin{array}{l}\text { Preliminary } \\
\text { Design } \\
\text { Length } \\
\text { (based on } \\
\text { Double } \\
\text { Pipe) [m] }\end{array}$ & $\begin{array}{l}\text { Recommended } \\
\text { Number of } \\
\text { Tubes }\end{array}$ & $\begin{array}{l}\text { Recommended } \\
\text { Configuration }\end{array}$ \\
\hline n-butane & 171.41 & 35 & $\begin{array}{l}1 \text { shell pass \& 1 } \\
\text { tube pass; OR } \\
\text { hairpin double } \\
\text { pipe }\end{array}$ \\
\hline & & & $\begin{array}{l}1 \text { shell pass \& 1 } \\
\text { tube pass; OR } \\
\text { hairpin double } \\
\text { pipe }\end{array}$ \\
\hline Isobutane & 48.79 & 10 & $\begin{array}{l}1 \text { shell pass \& 1 } \\
\text { tube pass; OR } \\
\text { hairpin double } \\
\text { pipe }\end{array}$ \\
\hline R 123 & 186.02 & 38 & $\begin{array}{l}1 \text { shell pass \& 1 } \\
\text { tube pass; OR } \\
\text { hairpin double } \\
\text { pipe }\end{array}$ \\
\hline & & & \multicolumn{2}{|c|}{} \\
\hline
\end{tabular}

In terms of working fluid performance the optimal results are obtained with isobutene, followed by n-butane, and then R245fa, and finally R123. Simulations in the other cycle components such as the turbine and condenser will, however, consider all four candidate working fluids with the aim of selecting the overall optimal choice. The information obtained in this exercise will be used in evaluating performance of the heat exchanger in the Infinity IT10 mini turbine cycle validation process as well as evaluating the correlations used in the heat transfer models.

Further figures 6 to 9 show that a glycol mass flow rate of 2.5 $\mathrm{kg} / \mathrm{s}$ is adequate for the two thermal loads of 4.2 and 16.8 $\mathrm{kWth}$ for all four working fluids both in terms of shell side pressure drops and fluid velocities; the corresponding tube side pressure drops are found to be insignificant and fluid velocities very low as can be seen from figures 11 (only showing tube side pressure drops for $84.2 \mathrm{kWth}$ ) and 13 respectively; the concern with extremely low tube side fluid velocities is that it may slow down or hinder optimal heat transfer. These results also show that for the two thermal loads the lowest cost of heat exchanger is that based on isobutene as the working fluid.

Figure 10 on the other hand shows that none of the models for the $84.2 \mathrm{kWth}$ meets the requirements for the shell side pressure drops; it also shows that the glycol mass flow rate must range from 2 to $5 \mathrm{~kg} / \mathrm{s}$ in order to satisfy the thermal load. The models produced prohibitive pressure drops ranging from 250 to $900 \mathrm{kPa}$ for the other three working fluids, other than isobutene and it was on the account of such excessive pumping requirements that table 4 was generated proposing a rethink of the heat exchanger models for this thermal load.
The mass flow rates for the working fluids determined by the parametric analyses for the three thermal loads are shown in figure 14; the actual figures are $0.010 \mathrm{~kg} / \mathrm{s}, 0.041 \mathrm{~kg} / \mathrm{s}$ and $0.207 \mathrm{~kg} / \mathrm{s}$ respectively for $4.2,16.8$ and $84.2 \mathrm{kWth}$ for $\mathrm{n}$ butane; the corresponding values for isobutene are $0.012,0.048$ and $0.241 \mathrm{~kg} / \mathrm{s}$; for R123 they are $0.022,0.088$ and $0.440 \mathrm{~kg} / \mathrm{s}$; and finally for R245fa they are $0.020,0.079$ and $0.396 \mathrm{~kg} / \mathrm{s}$. The lowest working fluid mass flow rates are attained with nbutane, followed by isobutene whilst $\mathrm{R} 123$ requires the highest mass flow rates followed by $\mathrm{R} 245 \mathrm{fa}$.

\section{Conclusions and Recommendations}

A heat exchanger model for the low temperature solar thermal organic Rankine cycle has been developed and evaluated on the EES platform. Parameters considered included heat exchanger size, pressure drop and fluid velocity on both the tube and shell sides. Reference values have been based on the tubular exchanger manufacturers association (TEMA) standards. Results have been analysed and discussed. The results have shown that models developed with isobutene as the working fluid are the most optimal from the four candidate working fluids tested. Further evaluations of the models and the correlations will be performed with the validation of the Infinity IT10 mini turbine ORC cycle.

Further the models developed satisfy the thermal loads, pressure drops and fluid velocities for the 4.2 and $16.8 \mathrm{kWth}$ loads. On account of very high pressure drops and therefore costly pumping requirements it has been proposed to redesign the heat exchanger model for the $84.2 \mathrm{kWth}$ to a multi-tube shell and tube heat exchanger.

It has also been established that a further conceptual investigation of two phase flow pressure drop be undertaken to fully appreciate its effect on the development of the heat exchanger models.

\section{Acknowledgments}

The authors would like to thank the Centre for Engineering Postgraduate Studies (CEPS) at University of KwaZulu-Natal for providing funds for certain aspects of the research as well as all colleagues, postgraduate students and staff of the section

\section{References}

[1] Situmbeko S. M., Inambao F. L. Mathematical Modelling and Simulation of Low Temperature Solar Thermal Energy Conversion Systems. Proceedings of Solar World Congress. Kassel, Germany, 2011.

[2] Thirumaleshwars M. Software Solutions to Problems of Heat Transfer, Heat Exchangers. ISBN 978-87-403-05784, Bookboon.com, 2013.

[3] Incropera F.P. etal. Fundamentals of Heat and Mass Transfer. John Wiley \& Sons. USA, 2007.

[4] EES32\Userlib\HeatTransfer|FoulingFactors\ FoulingFactor.lkt. 2013.

[5] Thome J.R. Engineering Data Book III; chapter 10: Fundamentals of Evaporation in Plain Tubes, Laboratory of Heat and Mass Transfer. Swiss Federal Institute of Technology. Lausanne, Switzerland.

[6] Thome J.R. Engineering Data Book III; chapter 9: Fundamentals of Boiling on Tubes and Tube Bundles, Laboratory of Heat and Mass Transfer, Swiss Federal Institute of Technology. Lausanne, Switzerland. 
[7] Website: slideshare.net/rijumoniboro/heat-exchangers12606868

[8] Website: razifar.com/cariboost_files/Heat_20 Exchangers.pdf

[9] Website: unix.ecs.umass.edu/ rlaurenc/Courses/che333/ Reference/exchanger.pdf

[10] Perry R.H. etal. Perry's Chemical Engineers' Handbook. 7th Edition, McGraw-Hill, 1999

[11] Klein S.A., and Alvarado F.L. Engineering Equation Solver for Microsoft Windows Operating Systems. FChart Software, Middleton, USA. 2013
[12] Website: honeywell-refrigerants.com/Europe; honeywellgenetron-245a-orc-systems-brochure

[13] Website: infinityturbine.com - ORC Waste Heat Turbine

[14] Website: energy.siemens.com - power-generation steam turbines, SST-6000 Brochure, T_6000_Series_Datasheet.pdf

[15] Website: energy.siemens.com, power-generation steam turbines, SST-300.pdf 


\section{Appendix: Simulation Results}

\begin{tabular}{|c|c|c|c|c|c|c|c|c|c|c|c|c|c|c|c|c|c|c|c|}
\hline \begin{tabular}{|l|} 
Latont HX \\
Soction 2 \\
Ovorall \\
Hoat \\
Trannffor \\
Coofficiont
\end{tabular} & \begin{tabular}{|l|} 
Latent HX \\
Soction 1 \\
Ovorall \\
Hoat \\
Tranffer \\
Coofficicitent
\end{tabular} & \begin{tabular}{|l} 
Sonsible \\
IIX Ovorall \\
Hoat \\
Tranffor \\
Coofficiont
\end{tabular} & \begin{tabular}{|l|} 
Working \\
Fuid \\
Boiling \\
Tempera \\
ture
\end{tabular} & \begin{tabular}{|l|} 
Hoat \\
Transfor \\
Fhid \\
Pinch \\
Point \\
Tempera
\end{tabular} & \begin{tabular}{|l|} 
Hoat \\
Trannfor \\
Fhid \\
outlot \\
Tempora \\
thre
\end{tabular} & \begin{tabular}{|l} 
\\
Working \\
Fluid \\
Volocity
\end{tabular} & \begin{tabular}{|l} 
Heat \\
Tranffor \\
Fluid \\
Maximum \\
Velocity
\end{tabular} & \begin{tabular}{|l} 
Total \\
IIX \\
Tubo \\
Propkure \\
Drop
\end{tabular} & \begin{tabular}{|l} 
Total \\
IIX \\
Sholl \\
Proknur \\
o Drop
\end{tabular} & \begin{tabular}{|l} 
\\
\\
Total \\
HX \\
Longth
\end{tabular} & \begin{tabular}{|l} 
Latont \\
IIX \\
Longth
\end{tabular} & $\begin{array}{l}\text { Sonkib lo } \\
\text { HX } \\
\text { Length }\end{array}$ & $\begin{array}{l}\text { Latont } \\
\text { Thernal } \\
\text { Load }\end{array}$ & $\begin{array}{l}\text { Sonnib lo } \\
\text { Thernal } \\
\text { Load }\end{array}$ & $\begin{array}{l}\text { Total } \\
\text { Thennal } \\
\text { Load }\end{array}$ & \begin{tabular}{|l} 
High \\
Prognure
\end{tabular} & \begin{tabular}{|l} 
Heat \\
Tranufer \\
Fluid \\
Mars \\
Floux \\
Rate
\end{tabular} & \begin{tabular}{|l|} 
Working \\
Fluid \\
Mars \\
Flow \\
Rate
\end{tabular} & $\begin{array}{l}\text { Working } \\
\text { Fhid }\end{array}$ \\
\hline$\left[\mathrm{W} / \mathrm{m}^{\wedge} 2-\mathrm{C}\right]$ & [ $\left.\mathrm{W} / \mathrm{m}^{\prime \prime} 2-\mathrm{C}\right]$ & {$\left[\mathrm{M} / \mathrm{ml}^{\mathrm{N}} \mathrm{2}-\mathrm{C}\right]$} & [C] & [C] & [C] & {$[\mathrm{nu} / \mathrm{u}]$} & {$[\mathrm{m} / \mathrm{h}]$} & {$[\mathrm{kPa}]$} & {$[\mathrm{kPa}]$} & [m] & {$[\mathrm{m}]$} & {$[\mathrm{m}]$} & {$[\mathrm{W}]$} & {$[\mathrm{W}]$} & {$[\mathrm{W}]$} & [kPa] & {$[\mathrm{kg} / \mathrm{kg}]$} & {$[\mathrm{kg} / \mathrm{l}]$} & \\
\hline 1207 & 824.1 & 139.2 & 80.03 & 88.33 & 87.68 & 0.06569 & 0.9964 & 0.0019 & 1.35 & 9.927 & 4.729 & 5.198 & 3023 & 1177 & 4200 & $1.01 \mathrm{E}+06$ & 0.5 & 0.01032 & n-butano \\
\hline 1395 & 944.2 & 141.8 & 80.03 & 89.16 & 88.84 & 0.06569 & 1.993 & 0.0017 & 3.98 & 8.758 & 3.907 & 4.851 & 3023 & 1177 & 4200 & $1.01 E+06$ & 1 & 0.01032 & n-butane \\
\hline 1475 & 994.5 & 142.8 & 80.03 & 89.44 & 89.23 & 0.06569 & 2.989 & 0.0016 & 7.78 & 8.383 & 3.643 & 4.74 & 3023 & 1177 & 4200 & $1.01 \mathrm{E}+06$ & 1.5 & 0.01032 & n-butanc \\
\hline 1521 & 1023 & 143.3 & 80.03 & 89.58 & 89.42 & 0.06569 & 3.985 & 0.0016 & 12.65 & 8.196 & 3.511 & 4.685 & 3023 & 1177 & 4200 & $1.01 \mathrm{E}+06$ & 2 & 0.01032 & n-butane \\
\hline 1551 & 1041 & 143.7 & 80.03 & 89.67 & 89.54 & 0.06569 & 4.982 & 0.0015 & 18.53 & 8.082 & 3.43 & 4.652 & 3023 & 1177 & 4200 & $1.01 \mathrm{E}+06$ & 2.5 & 0.01032 & n-butane \\
\hline 1207 & 839.9 & 334.9 & 80.03 & 83.3 & 80.68 & 0.2628 & 0.9964 & 0.0899 & 5.86 & 42.52 & 29.41 & 13.11 & 12091 & 4709 & 16800 & $1.01 \mathrm{E}+06$ & 0.5 & 0.04129 & n-butane \\
\hline 1395 & 969.1 & 351.9 & 80.03 & 86.65 & 85.35 & 0.2628 & 1.993 & 0.0578 & 12.53 & 27.398 & 18.2 & 9.198 & 12091 & 4709 & 16800 & $1.01 E+06$ & 1 & 0.04129 & n-butano \\
\hline 1475 & 1024 & 358.5 & 80.03 & 87.77 & 86.9 & 0.2628 & 2.989 & 0.0512 & 22.58 & 24.254 & 15.89 & 8.364 & 12091 & 4709 & 16800 & $1.01 \mathrm{E}+06$ & 1.5 & 0.04129 & n-butano \\
\hline 1521 & 1055 & 362 & 80.03 & 88.33 & 87.68 & 0.2628 & 3.985 & 0.0482 & 35.35 & 22.863 & 14.87 & 7.993 & 12091 & 4709 & 16800 & $1.01 \mathrm{E}+06$ & 2 & 0.04129 & n-butane \\
\hline 1551 & 1075 & 364.2 & 80.03 & 88.66 & 88.14 & 0.2628 & 4.982 & 0.0465 & 50.68 & 22.062 & 14.28 & 7.782 & 12091 & 4709 & 16800 & $1.01 \mathrm{E}+06$ & 2.5 & 0.04129 & n-butane \\
\hline 1521 & 1300 & 790 & 80.03 & 81.6 & 78.31 & 1.317 & 3.985 & 6.354 & 267.74 & 171.41 & 135.5 & 35.91 & 60599 & 23601 & 84200 & $1.01 \mathrm{E}+06$ & 2 & 0.207 & n-butanc \\
\hline 1551 & 1324 & 802.2 & 80.03 & 83.29 & 80.66 & 1.317 & 4.982 & 4.717 & 294.54 & 127.29 & 99.81 & 27.48 & 60599 & 23601 & 84200 & $1.01 E+06$ & 2.5 & 0.207 & n-butane \\
\hline 1572 & 1341 & 810.7 & 80.03 & 84.41 & 82.22 & 1.317 & 5.978 & 4.1027 & 353.76 & 110.72 & 86.59 & 24.13 & 60599 & 23601 & 84200 & $1.01 \mathrm{E}+06$ & 3 & 0.207 & n-butanc \\
\hline 1588 & 1353 & 817 & 80.03 & 85.21 & 83.33 & 1.317 & 6.975 & 3.7671 & 427.29 & 101.7 & 79.44 & 22.26 & 60599 & 23601 & 84200 & $1.01 \mathrm{E}+06$ & 3.5 & 0.207 & n-butano \\
\hline 1619 & 1377 & 828.8 & 80.03 & 86.65 & 85.34 & 1.317 & 9.964 & 3.2975 & 706.91 & 89.04 & 69.45 & 19.59 & 60599 & 23601 & 84200 & $1.01 \mathrm{E}+06$ & 5 & 0.207 & $\mathrm{n}$-butane \\
\hline 1207 & 746.2 & 107.4 & 81.35 & 88.24 & 87.68 & 0.05339 & 0.9964 & 0.0043 & 1.70 & 12.499 & 6.237 & 6.262 & 3175 & 1025 & 4200 & 506625 & 0.5 & 0.02192 & R 123 \\
\hline 1395 & 857.3 & 109 & 81.35 & 89.12 & 88.84 & 0.05339 & 1.993 & 0.0037 & 4.96 & 10.901 & 5.075 & 5.826 & 3175 & 1025 & 4200 & 506625 & 1 & 0.02192 & R 123 \\
\hline 1475 & 903.5 & 109.6 & 81.35 & 89.41 & 89.23 & 0.05339 & 2.989 & 0.0036 & 9.65 & 10.402 & 4.712 & 5.69 & 3175 & 1025 & 4200 & 506625 & 1.5 & 0.02192 & R 123 \\
\hline 1521 & 929.4 & 109.9 & 81.35 & 89.56 & 89.42 & 0.05339 & 3.985 & 0.0035 & 15.66 & 10.154 & 4.531 & 5.623 & 3175 & 1025 & 4200 & 506625 & 2 & 0.02192 & R 123 \\
\hline 1551 & 946.2 & 110.1 & 81.35 & 89.65 & 89.54 & 0.05339 & 4.982 & 0.0034 & 22.93 & 10.004 & 4.422 & 5.582 & 3175 & 1025 & 4200 & 506625 & 2.5 & 0.02192 & R 123 \\
\hline 1207 & 810.4 & 271.2 & 81.35 & 82.96 & 80.68 & 0.2136 & 0.9964 & 0.2396 & 8.77 & 63.68 & 46.4 & 17.28 & 12699 & 4101 & 16800 & 506625 & 0.5 & 0.0877 & R 123 \\
\hline 1395 & 925.1 & 282.3 & 81.35 & 86.49 & 85.35 & 0.2136 & 1.993 & 0.1312 & 15.97 & 34.93 & 24.04 & 10.89 & 12699 & 4101 & 16800 & 506625 & 1 & 0.0877 & R 123 \\
\hline 1475 & 974.4 & 286.5 & 81.35 & 87.66 & 86.9 & 0.2136 & 2.989 & 0.1138 & 28.19 & 30.299 & 20.51 & 9.789 & 12699 & 4101 & 16800 & 506625 & 1.5 & 0.0877 & R 123 \\
\hline 1521 & 1002 & 288.8 & 81.35 & 88.24 & 87.68 & 0.2136 & 3.985 & 0.1063 & 43.80 & 28.328 & 19.01 & 9.318 & 12699 & 4101 & 16800 & 506625 & 2 & 0.0877 & R 123 \\
\hline 1551 & 1020 & 290.2 & 81.35 & 88.59 & 88.14 & 0.2136 & 4.982 & 0.1022 & 62.52 & 27.225 & 18.17 & 9.055 & 12699 & 4101 & 16800 & 506625 & 2.5 & 0.0877 & R 123 \\
\hline 1551 & 1322 & 694.6 & 81.35 & 82.95 & 80.66 & 1.07 & 4.982 & 12.206 & 430.48 & 186.02 & 152.1 & 33.92 & 63647 & 20553 & 84200 & 506625 & 2.5 & 0.4395 & R 123 \\
\hline 1572 & 1339 & 701 & 81.35 & 84.12 & 82.22 & 1.07 & 5.978 & 9.73 & 473.84 & 148.3 & 120.3 & 28 & 63647 & 20553 & 84200 & 506625 & 3 & 0.4395 & R 123 \\
\hline 1588 & 1352 & 705.7 & 81.35 & 84.96 & 83.33 & 1.07 & 6.975 & 8.622 & 552.17 & 131.4 & 106.2 & 25.2 & 63647 & 20553 & 84200 & 506625 & 3.5 & 0.4395 & R 123 \\
\hline 1619 & 1375 & 714.6 & 81.35 & 86.48 & 85.34 & 1.07 & 9.964 & 7.241 & 876.56 & 110.41 & 88.84 & 21.57 & 63647 & 20553 & 84200 & 506625 & 5 & 0.4395 & R 123 \\
\hline 1207 & 827.9 & 117.6 & 80.99 & 88.34 & 87.68 & 0.05388 & 0.9964 & 0.0036 & 1.61 & 11.796 & 5.222 & 6.574 & 2994 & 1206 & 4200 & 810600 & 0.5 & 0.01975 & R245fa \\
\hline 1395 & 950.9 & 119.5 & 80.99 & 89.17 & 88.84 & 0.05388 & 1.993 & 0.0032 & 4.74 & 10.418 & 4.284 & 6.134 & 2994 & 1206 & 4200 & 810600 & 1 & 0.01975 & R245fa \\
\hline 1475 & 1002 & 120.2 & 80.99 & 89.45 & 89.23 & 0.05388 & 2.989 & 0.0031 & 9.26 & 9.982 & 3.987 & 5.995 & 2994 & 1206 & 4200 & 810600 & 1.5 & 0.01975 & R245fa \\
\hline 1521 & 1031 & 120.6 & 80.99 & 89.59 & 89.42 & 0.05388 & 3.985 & 0.003 & 15.06 & 9.764 & 3.838 & 5.926 & 2994 & 1206 & 4200 & 810600 & 2 & 0.01975 & R245fa \\
\hline 1551 & 1050 & 120.9 & 80.99 & 89.67 & 89.54 & 0.05388 & 4.982 & 0.0029 & 22.08 & 9.632 & 3.747 & 5.885 & 2994 & 1206 & 4200 & 810600 & 2.5 & 0.01975 & R245fa \\
\hline 1207 & 824.2 & 292.4 & 80.99 & 83.36 & 80.68 & 0.2155 & 0.9964 & 0.1787 & 7.28 & 52.88 & 35.96 & 16.92 & 11977 & 4823 & 16800 & 810600 & 0.5 & 0.07898 & R245fa \\
\hline 1395 & 959.7 & 305.3 & 80.99 & 86.68 & 85.35 & 0.2155 & 1.993 & 0.1081 & 14.64 & 32.02 & 20.59 & 11.43 & 11977 & 4823 & 16800 & 810600 & 1 & 0.07898 & R245fa \\
\hline 1475 & 1017 & 310.2 & 80.99 & 87.79 & 86.9 & 0.2155 & 2.989 & 0.0948 & 26.15 & 28.1 & 17.74 & 10.36 & 11977 & 4823 & 16800 & 810600 & 1.5 & 0.07898 & R245fa \\
\hline 1521 & 1050 & 312.9 & 80.99 & 88.34 & 87.68 & 0.2155 & 3.985 & 0.089 & 40.82 & 26.397 & 16.51 & 9.887 & 11977 & 4823 & 16800 & 810600 & 2 & 0.07898 & R245fa \\
\hline 1551 & 1071 & 314.6 & 80.99 & 88.67 & 88.14 & 0.2155 & 4.982 & 0.0857 & 58.42 & 25.442 & 15.82 & 9.622 & 11977 & 4823 & 16800 & 810600 & 2.5 & 0.07898 & R245fa \\
\hline 1521 & 1286 & 721.9 & 80.99 & 81.68 & 78.31 & 1.08 & 3.985 & 14.219 & 375.82 & 240.57 & 191.2 & 49.37 & 60030 & 24170 & 84200 & 810600 & 2 & 0.3958 & R245fa \\
\hline 1551 & 1310 & 732.1 & 80.99 & 83.35 & 80.66 & 1.08 & 4.982 & 9.142 & 358.04 & 154.75 & 120.8 & 33.95 & 60030 & 24170 & 84200 & 810600 & 2.5 & 0.3958 & R245fa \\
\hline 1572 & 1327 & 739.2 & 80.99 & 84.46 & 82.22 & 1.08 & 5.978 & 7.706 & 416.82 & 130.48 & 101.3 & 29.18 & 60030 & 24170 & 84200 & 810600 & 3 & 0.3958 & R245fa \\
\hline 1588 & 1339 & 744.4 & 80.99 & 85.25 & 83.33 & 1.08 & 6.975 & 6.978 & 496.40 & 118.16 & 91.49 & 26.67 & 60030 & 24170 & 84200 & 810600 & 3.5 & 0.3958 & R245fa \\
\hline 1619 & 1362 & 754.2 & 80.99 & 86.68 & 85.34 & 1.08 & 9.964 & 6.002 & 807.32 & 101.7 & 78.48 & 23.22 & 60030 & 24170 & 84200 & 810600 & 5 & 0.3958 & R245fa \\
\hline
\end{tabular}

